\section{Growth Control of Lisianthus by Photoselective Plastic Films}

\author{
Sandra B. Wilson ${ }^{1}$ and \\ Nihal C. Rajapakse ${ }^{2}$
}

AdDitional INDEX wORDS. Eustoma grandiflorum, spectral filters, greenhouse covers, photomorphogenesis, height control, light quality, far-red light.

\section{Summary. Plant response to} photoselective plastic films with varying spectral transmission properties was tested using lisianthus (Eustoma grandiflorum) 'Florida Pink', 'Florida Blue', and 'Florida Sky Blue'. Films were designated YXE-10 (far-red light-absorbing film) and SXE-4 (red light absorbing film). Light transmitted through YXE-10 films reduced plant height compared to control plants by $10 \%$ ('Florida Blue'), and stem dry weight by $19 \%$ to $40 \%$, but the response varied by cultivar. Internode length was reduced by $10 \%$ to $19 \%$ when 'Florida Pink' and 'Florida Sky Blue' plants were grown under YXE-10 films. Leaf and root dry weights were not affected by YXE-10 films, with the exception that 'Florida Sky Blue' plants had a lower leaf dry weight than the control plants. Light transmitted through SXE-4 films increased plant height of 'Florida Pink' plants by $15 \%$ but not of 'Florida Blue' or 'Florida Sky Blue.' Regardless of cultivar, dry weight of leaf, stem and root tissue was not affected by SXE-4 films as compared to control films. The average number of days to flower and bud number were not affected by YXE-10 or SXE4 films, regardless of cultivar. The results suggest that selective reduction

Florida Agricultural Experiment Station journal series R-07838. Authors would like to thank Laurie Krumfolz for her technical assistance and PanAmerican Seed Co. for donating the plant material. The cost of publishing this paper was defrayed in part by the payment of page charges. Under postal regulations, this paper therefore must be hereby marked advertisement solely to indicate this fact.

${ }^{1}$ University of Florida, IFAS, Indian River Research and Education Center, Fort Pierce, Fla 34945; e-mail sbwilson@gnv.ifas.ufl.edu.

${ }^{2}$ Clemson University, Department of Horticulture, Clemson, SC 29364 of far-red wavelengths from sunlight may be an alternative technique for greenhouse production of compact plants, but the magnitude of the response is cultivar specific.

$L$ isianthus production has become one of the fastest growing segments of the floriculture trade as plants are marketed for cut flowers, bedding, and flowering pot purposes. In addition, new cultivars have been bred for heat tolerance, basal branching, and uniform response to growth retardants (Harbaugh and Scott, 1999). Chemical growth regulators are routinely used to reduce plant height, obtain more consistent plant size, and facilitate shipping (Norcini et al., 1996; Styer and Koranski, 1997). However, due to perceived risks to humans and the environment, the use of some chemical growth regulators has been severely restricted for ornamental use and completely banned for use on food crops. The drive towards sustainable agriculture and best management practices necessitates the need for nonchemical alternatives to regulate growth (e.g., height) of greenhouse crops. Although environmental manipulations can reduce use of chemical growth regulators, the costs associated with comply- ing with chemical regulation may increase to the point that it may not be economical to use some plant growth regulators (Norcini et al., 1996). Furthermore, the efficacy of chemical growth regulators (with relation to application rate, timing, and product) is species-specific and crops that are relatively new to production are often not included on growth regulator labels (Schoellhorn and Barrett, 1999).

As an alternative to using chemicals, light quality in the greenhouse can be manipulated by using photoselective greenhouse covers to control height of some greenhouse crops. Height control by photoselective films can be achieved by altering the balance between the far-red light absorbing form of phytochrome (Pfr) and the total phytochrome present in the plants through the manipulation of red (R) (600 to $700 \mathrm{~nm}$ ) and far-red (FR) (700 to $800 \mathrm{~nm}$ ) light entering the greenhouse. Longer stems produced under $\mathrm{R}$ light absorbing films may prove beneficial to the cut flower industry while shorter stems produced under FR light absorbing films may be advantageous to the bedding plant industry. The potential commercial applications of photoselective films have driven several international plastic manufacturers to develop plastics with various spectral properties

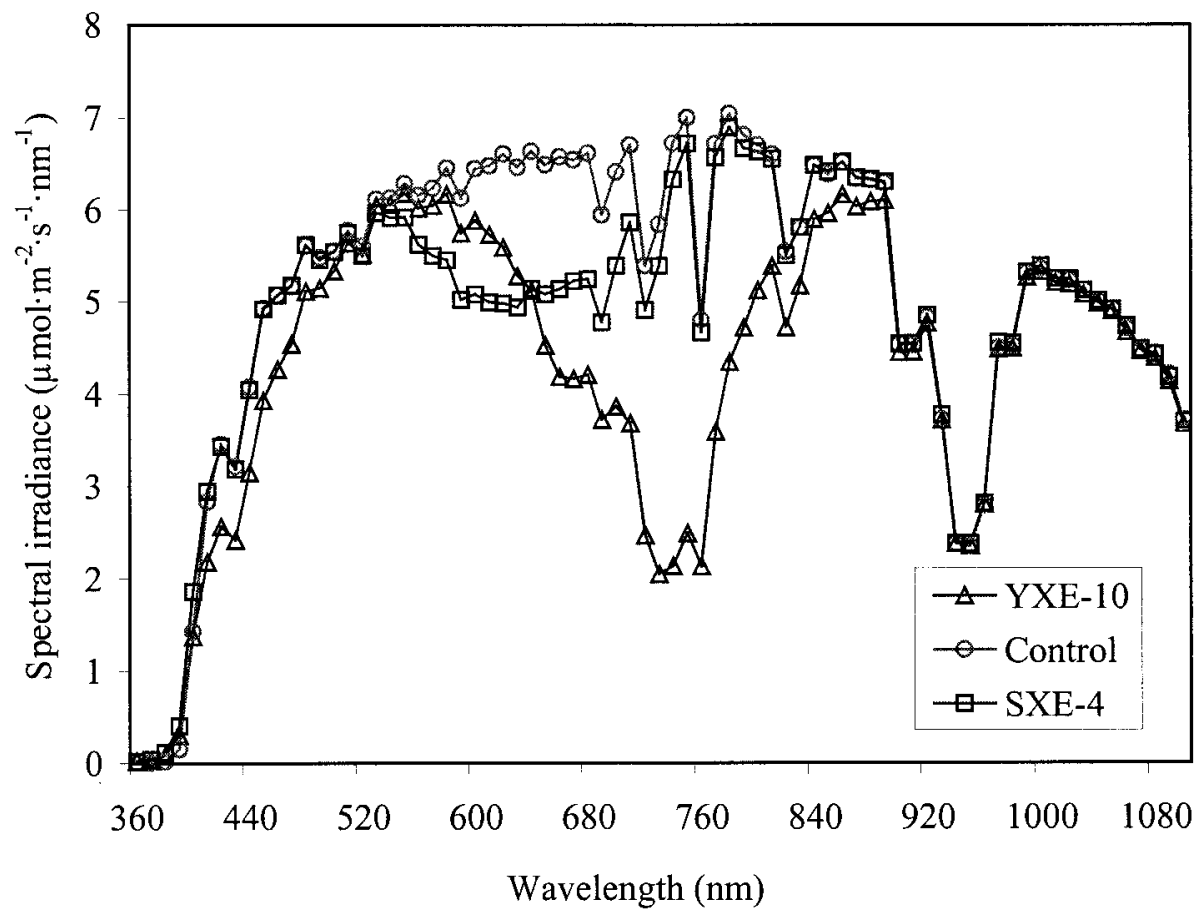

Fig. 1. Spectral transmission properties of YXE-10 (far-red light absorbing) and SXE-4 (red light absorbing) photoselective films. Control film is polyethylene without light absorbing dye. 
Table 1.Red:far-red (R:FR) ${ }^{\mathrm{z}}$ ratios and estimated phytochromephotoequilibrium(Pfr/ P) ${ }^{y}$ of light transmitted through photoselective films. YXE-10 = far-red light absorbing film, SXE-4 = red light absorbing film. Control film is aclear polyethylenefilm.

\begin{tabular}{lcc}
\hline Treatment & R:FR & (Pfr/P) \\
\hline YXE-10 & 1.48 & 0.76 \\
SXE-4 & 0.85 & 0.69 \\
Control & 1.02 & 0.71 \\
\hline
\end{tabular}

${ }^{\mathrm{z}} \mathrm{R}=600-700 \mathrm{~nm}$ waveband red light; $\mathrm{FR}=700-800 \mathrm{~nm}$ waveband far-red light.

${ }^{y}$ Estimated as described by Sager et al. (1988); Pfr = far-red absorbing form of phytochrome, $\mathrm{P}=$ total phytochrome.
Fig. 2. Effect of YXE-10 (far-red light absorbing) and SXE-4 (red light absorbing) photoselective films on plant growth oflisianthus'FloridaPink'(A), 'Florida Blue'(B), and 'Florida SkyBlue' (C) after 8 weeks. Control film is polyethylenewithout light absorbing dye.
(Murakami etal., 1995; van Haeringen et al., 1998; Oyaert et al., 1999). These films regulate growth in a variety of vegetable and ornamental plant species (Rajapakse et al., 1999). The response depends on the species, cultivar, and even season of growth. The objective of this work was to determine the effects of photoselective greenhouse films on three lisianthus cultivars, 'Florida Pink', 'Florida Blue', and 'Florida Sky Blue'.

\section{Materials and methods}

Photoselective chambers. Chambers $[90 \times 60 \times 104 \mathrm{~cm}(36 \times 24$ $\times 41$ inches $)]$ framed with polyvinyl chloride (PVC) pipe were covered with experimental, photoselective polyethylene films and placed in a glass greenhouse. Films were identified by code names YXE-10 (FR light-absorbing film), SXE-4 (R light-absorbing film), and control (clear film without light absorbing dye) (Mitsui Chemicals, Inc., Tokyo, Japan). One exhaust fan $\left[25,957 \mathrm{~cm}^{3} \cdot \mathrm{s}^{-1}\left(55 \mathrm{ft}^{3} / \mathrm{min}\right), \mathrm{W} . W\right.$. Grainger, Inc., West Palm Beach, Fla.] was placed in the opposite side of each chamber from a $10-\mathrm{cm}$ (4-inch) door opening to provide constant airflow and prevent heat buildup. Spectral distribution of light transmitted through films was measured at the beginning and end of the experiment (Fig. 1) using a spectroradiometer (LI-1800; LI-COR Inc., Lincoln, Nebr) and it was confirmed that the spectral integrity of the films was unaltered during the experiment. The R:FR ratio of transmitted light was calculated as the photon flux ratio between 600 and $700 \mathrm{~nm}$ waveband (R) and 700 and $800 \mathrm{~nm}$ waveband (FR) (Table $\mathrm{l}$ ). Phytochrome photoequilibrium (Pfr/ $\mathrm{P}$ ) (amount of phytochrome in the Pfr form relative to total phytochrome) was calculated (Sager et al., 1988) using the spectroradiometer data between 350 and $850 \mathrm{~nm}$ (Table $\mathrm{l}$ ). Both R:FR ratios and Pfr/P have been commonly used to quantitatively char-
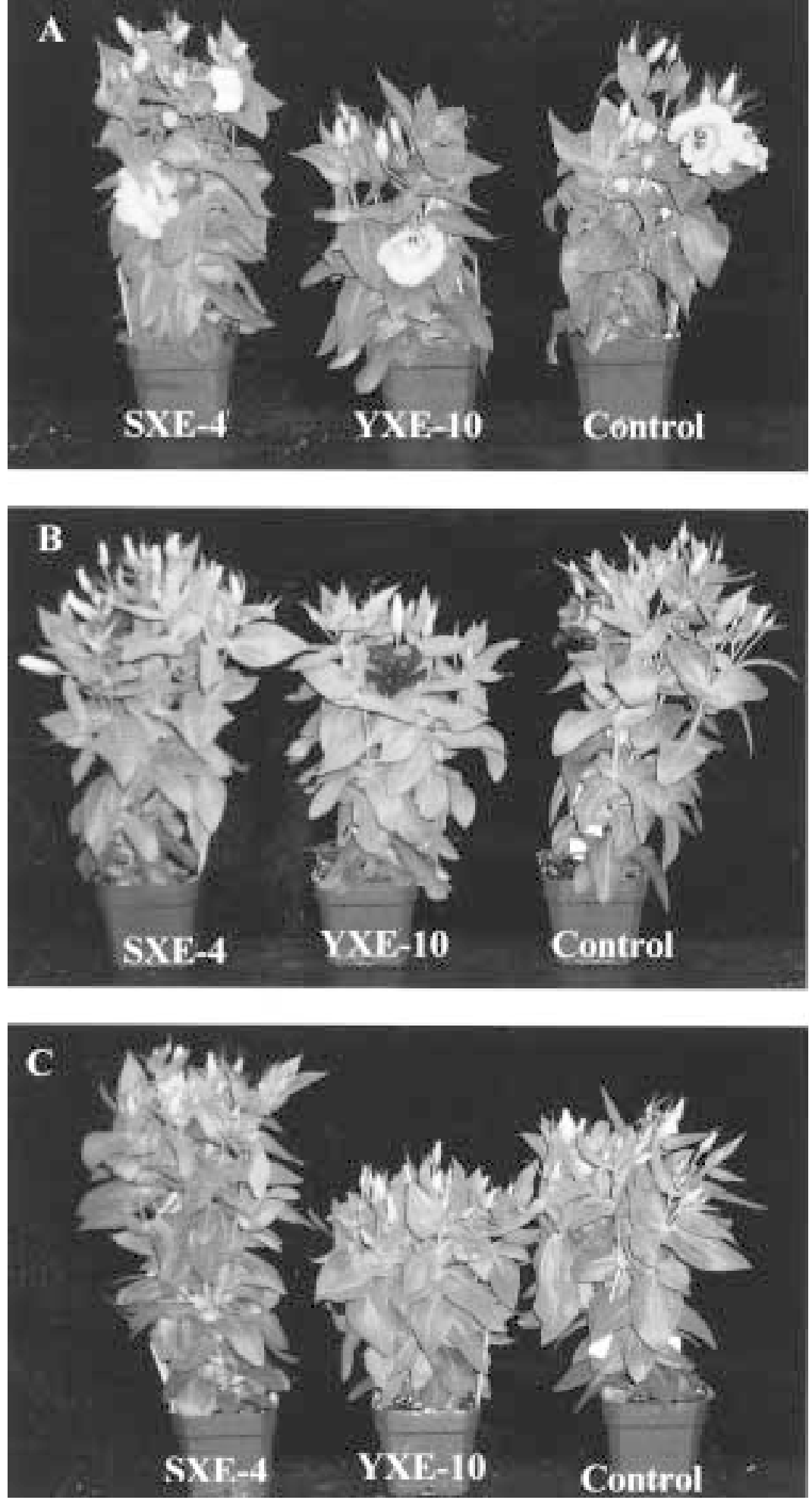
Table 2. Growth characteristics of lisianthus 'Florida Pink', 'Florida Blue', and 'Florida Sky Blue' grown for 8 weeks under greenhouse photoselective films with varying red:far-red $(\mathrm{R}: \mathrm{FR})^{\mathrm{z}}$ ratios. $\mathrm{YXE}-10$ = far-red light absorbing film; SXE-4 = red light absorbing film; control film is clear polyethylene; $2.54 \mathrm{~cm}=1.0 \mathrm{inch} ; 28.35 \mathrm{~g}=1.0 \mathrm{oz}$.

\begin{tabular}{|c|c|c|c|c|c|c|c|c|c|}
\hline Cultivar & $\begin{array}{c}\text { Film } \\
\text { treatment }\end{array}$ & $\begin{array}{c}\text { Plant } \\
\text { ht } \\
(\mathbf{c m})\end{array}$ & $\begin{array}{c}\text { Internode } \\
\text { length } \\
\text { (cm) }\end{array}$ & $\begin{array}{c}\text { No. } \\
\text { of } \\
\text { buds }\end{array}$ & $\begin{array}{c}\text { Days } \\
\text { to } \\
\text { flower }\end{array}$ & $\begin{array}{c}\text { Leaf } \\
\text { drywt } \\
(\mathrm{g})\end{array}$ & $\begin{array}{c}\text { Stem } \\
\text { drywt } \\
(\mathbf{g})\end{array}$ & $\begin{array}{c}\text { Root } \\
\text { drywt } \\
\text { (g) }\end{array}$ & $\begin{array}{c}\text { Shoot } \\
\text { to root } \\
\text { ratio }\end{array}$ \\
\hline \multirow[t]{4}{*}{ 'Florida Pink' } & Control & $23.6 b^{y}$ & $1.15 \mathrm{~b}$ & 33.8 & 25.6 & 4.66 & $1.81 \mathrm{a}$ & 1.26 & $5.45 \mathrm{a}$ \\
\hline & SXE-4 & $27.2 \mathrm{a}$ & $1.24 \mathrm{a}$ & 37.8 & 26.6 & 4.65 & $1.94 \mathrm{a}$ & 1.26 & $5.33 \mathrm{ab}$ \\
\hline & YXE-10 & $22.5 \mathrm{~b}$ & $1.04 \mathrm{c}$ & 34.7 & 25.2 & 4.08 & $1.31 \mathrm{~b}$ & 1.42 & $4.22 \mathrm{~b}$ \\
\hline & Significance ${ }^{x}$ & $\star * *$ & $* \star *$ & NS & NS & NS & $\star * *$ & NS & * \\
\hline \multirow[t]{4}{*}{ 'Florida Blue' } & Control & $31.2 \mathrm{a}$ & 1.34 & 39.5 & 29.7 & 5.14 & $2.74 \mathrm{a}$ & 2.37 & 3.96 \\
\hline & SXE-4 & $30.4 \mathrm{a}$ & 1.36 & 42.1 & 28.2 & 4.38 & $2.59 \mathrm{ab}$ & 1.83 & 3.93 \\
\hline & YXE-10 & $27.9 \mathrm{~b}$ & 1.27 & 32.4 & 31.3 & 5.00 & $2.22 \mathrm{~b}$ & 2.46 & 3.22 \\
\hline & Significance & * & NS & NS & NS & NS & * & NS & NS \\
\hline \multirow[t]{4}{*}{ 'Florida Sky Blue' } & Control & $26.7 \mathrm{ab}$ & $1.16 \mathrm{a}$ & 46.5 & 30.1 & $5.92 \mathrm{a}$ & $2.62 \mathrm{a}$ & 2.33 & 4.59 \\
\hline & SXE-4 & $28.1 \mathrm{a}$ & $1.18 \mathrm{a}$ & 55.4 & 29.8 & $5.75 \mathrm{ab}$ & $2.72 \mathrm{a}$ & 1.91 & 5.02 \\
\hline & YXE-10 & $23.4 \mathrm{~b}$ & $0.94 \mathrm{~b}$ & 42.3 & 31.5 & $4.87 \mathrm{~b}$ & $1.56 \mathrm{~b}$ & 1.31 & 4.98 \\
\hline & Significance & * & $* *$ & NS & NS & * & $* * *$ & NS & NS \\
\hline
\end{tabular}

${ }^{\mathrm{z}} \mathrm{R}=600-700 \mathrm{~nm}$ waveband red light; $\mathrm{FR}=700-800 \mathrm{~nm}$ waveband far-red light.

${ }^{y}$ Means followed by same letter within cultivar are not significant at $P=0.05$.

Ns, $,{ }^{\star \star \star},{ }^{\star * \star}$ Nonsignificant or significant response at $P=0.05,0.01$, or 0.001 , respectively.

acterize phytochrome-mediated plant responses (Rajapakse et al., 1999).

Plant material. Uniform microplugs of lisianthus Florida series 'Florida Pink', 'Florida Blue', and 'Florida Sky Blue' [about 2 to $3 \mathrm{~cm}$ (0.8 to 1.2 inches) tall with 10 leaves ] (PanAmerican Seed Co., Palmetto, Fla.) were planted into $10-\mathrm{cm}$ pots filled with soilless media (Fafard Mix \#2, Fafard, Inc., Apopka, Fla.). Plants were transferred to experimental chambers beginning 1 Feb 2000 for 8 weeks with a natural, 11 to $12 \mathrm{~h}$ photoperiod (lat. $27.43^{\circ} \mathrm{N}$, long. $80.41^{\circ} \mathrm{W}$ ). To ensure uniform light intensity, the photosynthetic photon flux (PPF) inside each chamber was measured at bench level with a quantum meter (LI-250; LI-COR), and chambers were adjusted at solar noon to $500 \pm 40 \mu \mathrm{mol} \cdot \mathrm{m}^{-2} \cdot \mathrm{s}^{-1}$ using cheesecloth. All plants were fertilized during irrigation twice a week at $400 \mathrm{mg} \cdot \mathrm{L}^{-1}(\mathrm{ppm})$ of nitrogen from Peter's Special 20-10-20 (20N-4.4P16.6K) (Scotts Co., Marysville, Ohio). Plants were treated with a $1 \%$ granular systemicinsecticide, imidacloprid (Marathon) at a standard rate of $1.4 \mathrm{~g}(0.05$ oz) per pot (Olympic Horticultural Products, Bradenton, Fla.) and a broad spectrum systemic fungicide, etridiazole/thiophanate-methyl (Banrot) at a standard rate of $12.9 \mathrm{~g} \cdot \mathrm{L}^{-1}$ $(0.12 \mathrm{oz} / \mathrm{gal})$ (Scotts Co., Marysville, Ohio). Plants were inspected daily and hand watered as needed. Temperature inside and outside (greenhouse air temperature) of experimental chambers was recorded continually with a Ryan
Universal $\mathrm{K}$ temperature recorder (Ryan Instruments, Redmond, Wash.). Average minimum and maximum air temperatures inside the chambers were 16 and $35^{\circ} \mathrm{C}\left(61\right.$ and $\left.95^{\circ} \mathrm{F}\right)$, respectively.

Average internode length (plant height divided by number of leaves on main stem) was measured at $0,2,4,6$, and 8 weeks. Plant height (height from potting medium surface to apex of central stem), number of fully expanded leaves, number of flower buds, and dry weight of leaves, stems, and roots were recorded after 8 weeks. Flowering time was recorded at initial bud development. For dry weight measurements, tissue was oven-dried at $49{ }^{\circ} \mathrm{C}(120$ ${ }^{\circ} \mathrm{F}$ ) for 1 week.

EXPERIMENTAL DESIGN AND STATISTICAL ANALYSis. Experimental chambers were randomly placed in the greenhouse. Five plants of each cultivar were randomly arranged in each chamber. A split plot experimental design was used with two chambers per treatment. The whole plot was the film treatment and the split plot was the three cultivars tested. Data were analyzed using analysis of variance. Differences among treatment means were tested by Duncan's multiple range test at $P=0.05$.

\section{Results and discussion}

YXE-10 FILMs. Light transmitted through YXE-10 films reduced plant height of lisianthus 'Florida Blue' by $10 \%$ as compared to the control treatment (Fig. 2, Table 2). This is consid- erably less than the $36 \%, 24 \%$, and $25 \%$ reduction in plant height reported for cucumber (Cucumis sativus 'Sweet Success'), bell pepper (Capsicum annuum 'Capistrano'), and chrysanthemum (Dendranthemaxgrandiflorum ${ }^{`} Y \mathrm{el}-$ low Snowden'), respectively (Rajapakse et al., 1999). However, percentagesofheight reduction similar to those of lisianthus have been reported for snapdragon (Antirrbinum majus'Tahiti Red'), zinnia (Zinnia elegans 'Cherry Ruffles'), and chrysanthemum 'Iridon' grown under similar YXE-10 films (Rajapakse et al., 1999). Thus, it appears that the magnitude of height reduction varies with species and cultivar. Average internode length of lisianthus 'Florida Pink' and 'Florida Sky Blue' plants grown under YXE-10 films was reduced by $10 \%$ and $19 \%$, respectively, as compared to plants grown under control films (Fig. 2, Table 2). Node development was not significantly affected by the light transmitted through the YXE-10 or SXE-4 films (data not presented), indicating that the height reduction was mainly caused by a reduction in internode length. These differences in internode length were detected after as little as 2 or 4 weeks (data not presented). Cerny et al. (1999) reported that light transmitted through FR-absorbing films reduced height of bell peppers after as early as 1 week of exposure, and that the effects were more pronounced as time progressed.

Reduced plant height correlated with reduced stem dry weight of YXE- 
10 plants. 'Florida Pink', 'Florida Blue', and 'Florida Sky Blue' plants grown under YXE-10 films had 28\%, 19\%, and $40 \%$, respectively, less dry weight than control plants. This is consistent with research by Cerny et al. (1999) who showed that shoot dry weight of bell peppers decreased when grown under FR absorbing films with a similar R:FR ratio as in our experiment. Likewise, Li et al. (2000) showed that as the R:FR ratio of photoselective films increased, the percentage dry matter accumulation in chrysanthemum stems decreased from $34 \%$ (control) to $24 \%$. Leaf and root dry weights and shoot:root ratios were not influenced by spectral films, regardless of cultivar, with the exception that 'Florida Sky Blue' plants had a lower leaf dry weight and 'Florida Pink' plants had a lower shoot:root ratio than the control plants.

YXE-10 films did not delay flowering or reduce number of flower buds of any cultivars (Table 2). However, the effect of photoselective films on flowering appears to be dependent on whether the plants are photoperiodic. Flowering of cosmos (Cosmos bipinnatus), zinnia, and chrysanthemum (short-day plants) was only slightly delayed (by 1 to $2 \mathrm{~d}$ ) when grown under far-red light absorbing film; whereas, the flowering of snapdragon and petunia (Petuniasp.)(longday plants) was delayed by as much as 7 to $13 \mathrm{~d}$ when grown under short days and by 2 to $3 \mathrm{~d}$ when grown under long days (van Haeringen et al., 1998; Rajapakse et al., 2001). There is some discrepancy in the literature as to whether lisianthus are day-neutral plants (Halevy and Kofranek, 1984) or quantitative long-day plants (Roh et al., 1989). More recently, Harbaugh (1995) reported that cultivar and interactive effects of photoperiod and temperature influence the flowering percentage of lisianthus plants.

SXE-4 FILms. Compared with that of the control, light transmitted through SXE-4 films did not significantly affect plant height, bud number, flowering time, or plant dry weight of 'Florida Blue' and 'Florida Sky Blue' plants, but 'Florida Pink' plants were significantly taller (greater plant height and internode length) (Table 2, Fig. 2). Previously, R light-absorbing photoselective films (low R:FR ratios) were shown to increase plant height in other ornamentals such as snapdragon and petunia as well as a variety of vegetables (Rajapakse et al., 1999). Similarly, Murakami et al. (1995) showed that stem length of sunflowers (Helianthus annuus) increased by $21 \%$ in the R-intercepting treatment compared with the control treatment ten days after planting. Again, it appears that the magnitude of height manipulation varies with species.

\section{Conclusions}

Selective reduction of FR wavelengths from sunlight using the YXE10 FR-absorbing film reduced the height of lisianthus by 10\% ('Florida Blue') and reduced internode length by $10 \%$ and $19 \%$ ('Florida Pink' and 'Florida Sky Blue', respectively) without affecting the development of flowers or flower quality. However, the height reduction of lisianthus cultivars was less than that for some of the other crops that have been tested previously. Therefore, depending on the height reduction required, light manipulation alone may not be sufficient to attain height reduction. A combination of growth regulators with photoselective films could reduce the frequency and the amount of growth regulating chemicals needed to attain the desired height reduction, thereby reducing chemical exposure and decreasing environmental impacts.

\section{Literature cited}

Cerny, T.A., N.C. Rajapakse, and R. Oi. 1999. Recent developments in photoselective greenhouse covers. Proc. Natl. Agr. Plastics Congr. 28:75-80.

Halevy, A.H. and A.M. Kofranek. 1984. Evaluation of lisianthus as a new flower crop. HortScience 19:845-847.

Harbaugh, B.K. 1995. Flowering of Eustoma grandiflorum (Raf.) Shinn. cultivars influenced by photoperiod and temperature. HortScience 30:1375-1377.
Harbaugh, B.K. and J.W. Scott. 1999. 'Florida Pink' and 'Florida Light Blue' Semi-dwarf heat-tolerant cultivars of lisianthus. HortScience 34:364-365.

Li, S., N.C. Rajapakse, R.E. Young, and R. Oi. 2000. Growth responses of chrysanthemum and bell pepper transplants to photoselective plastic films. Scientia Hort. 84:215-225.

Murakami, K., H. Cui, M. Kiyota, and I. Aiga. 1995. The design of special covering materials for greenhouses to control plant elongation by changing spectral distribution of daylight. Acta Hort. 399:135-142.

Norcini, J.G., W.G. Hudson, M.P. Garber, R.K. Jones, A.R. Chase, and K. Bondari. 1996. Pest management in the U.S. Greenhouse and Nursery Industry: III. Plant growth regulation. HortTechnology 6:207-210

Oyaert, E., E. Volckaert, and P.C. Debergh. 1999. Growth of chrysanthemum under coloured plastic films with different light qualities and quantities. Scientia Hort. 79:195-205.

Rajapakse, N.C, R.E. Young, M.J. McMahon, and R. Oi. 1999. Plant height control by photoselective filters: current status and future prospects. HortTechnology 9:618-624.

Rajapakse, N.C., T.A. Cerny, S. Li, and R. Oi. 2001. Alteration of greenhouse environment by photoselective covers to produce compact plants. Acta Hort. (in press).

Roh, M.S., A.H. Halevy, and H.F. Wilkins. 1989. Eustoma grandiflorum, p. 322-327. In: A.H. Halevy (ed.). Handbook of flowering. vol. VI. CRC Press, Boca Raton, Fla.

Sager, J.C., W.O. Smith, J.L. Edwards, and K.L. Cyr. 1988. Photosynthetic efficiency and phytochrome photoequilibria determination using spectral data. Trans. Amer. Soc. Agr. Eng. 31:1882-1889.

Schoellhorn, R. and J. Barrett. 1999. Controlling the tropics. Ornamental Outlook 8(5):30-32.

Styer, R.C. and D.S. Koranski. 1997. Plug and transplant production, p. 241-257. Ball Publishing, Batavia, Ill.

van Haeringen, C.J., J.S. West, F.J. Davis, A. Gilbert, P. Hadley, S. Pearson, A.E. Wheldon, and R.G.C. Henbest. 1998. The development of solid spectral filters for the regulation of plant growth. Photochem. Photobiol. 67:407-413. 